\title{
Systemic approach to study of developing innovative banking services for remote customer service in Bashkortostan
}

\author{
Lyuza Bayguzina \\ Institute of Economics, Finance and Business \\ Associate Professor of the Department of Finance and \\ Taxation, Bashkir State University \\ Ufa, Russia \\ Lyuzab@mail.ru
}

\author{
Guzaliya Galimova \\ Institute of Economics, Finance and Business \\ Associate Professor of the Department of Finance and \\ Taxation, Bashkir State University \\ Ufa, Russia \\ ggalimova02@yandex.ru
}

\begin{abstract}
The aim of this paper is to study modern tendencies in the development of innovative banking services for remote customer service in Bashkortostan. The paper deals with the systemic approach to the analysis of foreign authors from various perspectives related to the world experience of introducing the Internet banking in the banking sector. The authors illustrate domestic expertise of development and introduction of banking services for remote customer service in Bashkortostan. It is noteworthy that various banks apply different approaches to the introduction of the Internet banking service in the customer base. The method of statistical analysis was implemented during the study, thus revealing the proportion of the Internet banking users in the total number of users with various incomes per capita in a family. It is specified that the vast majority of people applying the Internet banking are people with the average level of income, high income and low income. It is shown that there is a direct dependence between the experience of the Internet banking user and frequency of using this service. The majority of operations account for regular payments such as mobile communications, the Internet, transfers between accounts within the bank and payment of utilities. However, in spite of this fact, there are still restrictions and drawbacks while exploiting the systems that should be improved.
\end{abstract}

Keywords - remote customer service, tendencies of development, world experience, innovative product, banking services

\section{INTRODUCTION (WORLD EXPERIENCE OF FORMATION AND DEVELOPMENT OF THE INTERNET BANKING)}

The current development of the world banking system takes place under the conditions of escalating competition and crisis in financial markets. One of the most essential factors for the successful development of banking is the policy of continuous innovations. Nowadays, innovations are the key factor of stability, competitiveness and sustainable economic growth of both domestic and foreign commercial banks. If the given interdependence is taken into account, it is beyond dispute that studying modern tendencies of development of innovative banking services for remote customer service is an urgent scientific and practical need.

The beginning of rapid development of the Internet banking as such was laid about 20 years ago when a group of companies (Nottingham Building Society, British Telecom and Bank of Scotland) united their efforts to create a system that provides for online transfers. It became the first remote Banking System in 1983.

This innovation implied the beginning of transition of RBS from telephone networks and operator service centers to the Internet and specialized applications. But historically, the first system of such kind was the system of remote banking services functioning through mobile phones and landlines, while the first experiments related to the introduction of remote access systems were carried out by Western banks in the 1980s.

The most active banks were British banks since they were struggling with rigorous competition and looked for additional ways to attract customers. Therefore, the National Westminster Bank was the pioneer in the field of remote access. The customers of this bank had a great opportunity to make a phone call in real time in order to make some transactions, such as transfers into accounts within the bank, purchase and sale of foreign currency. The National Westminster Bank became the first bank to implement the remote access system. A customer could simply dial a bank number and make standard payments.

To manage an account, a customer shall enter a five-digit code. Later the system was improved along with the development of digital communication and the introduction of computer technologies. Subsequently, this innovation was embedded in Germany and Spain. This system became an indispensable banking tool within the conditions of inflationdriven economy in Latin America when individuals have to buy and sell currency and securities on a regular basis.

Thereby, international experience connected with the development of banking services for remote customer service was widely spread and introduced in other countries all over the world. 


\section{EASE OF USE}

\subsection{World approach to the study of the Internet banking:} practical experience

The banking industry has witnessed a quantum leap in technology during the last decade in its efforts to meet the ever-growing customer demand. Banks claim that consumers demand more sophisticated products and services and the decreased customer loyalty is putting more pressure on the banks to satisfy their demand [1]. A combination of different ways of making banking services available is likely to attract and retain the most satisfied and, thus, most loyal and least price-sensitive customers [2]. Therefore, banks have developed a variety of techniques and services to meet the customer needs and offer many different channels to access banking and other services such as Automated Teller Machines (ATM), telephone banking, online banking and mobile banking to the extent of providing SMS banking [3]

First of all, the paper focuses on the development and introduction of the Internet banking in developing countries. It will be useful to present the analysis of some countries. The systemic approach to studying the given problem was considered by such foreign authors as Al Kharusi, $\mathrm{MH}, \mathrm{Al}-$ Badi, AH noting that "The ability to provide public services has tremendously increased with the rapid advancements and development of IT infrastructure and the availability of the Internet. The aim is to ensure the scalability, flexibility and feasibility to meet the IT infrastructure demands, which can be achieved through the Cloud Computing Technology" [4]. G. Baptista, T. Oliveira in their report define the fact that in developing countries, especially in Africa, the mobile banking system can play a great role providing people with an opportunity to overcome financial exclusion and physical distance, enabling native dwellers to implement financial operations [5]. Besides, the approach to Internet banking used by Islamic banks is rather interesting. Thus, a group of authors discloses the fact that "service quality and customer role readiness are the two determining factors, whereas organizational support and organizational socialization are not pertinent aspects that support customers' attitudes towards internet banking. The customers of Islamic bank, similar to the conventional banks, prefer the Internet banking because they are ready to adopt the services. Sustainable competitive advantage is highly critical in the era of global business environment, especially with the development of technology. Hence, Islamic banks need to accelerate in creating innovative products and services in order to stay ahead in the banking industry" [6].

This method of payment can also be expanded and implemented by state administrations. The authors of the system, developed by the Central Bank of Ecuador, present an alternative model for the electronic money system proposed in the public sector, seeking to provide the Ecuadorian population with an alternative for economic integration and compatibility with various service providers and economic actors. This work presents the system design and comparison with other electronic payment projects. The results obtained are used to provide recommendations on how to improve and replicate the development of similar projects [7]
The study also describes the efficiency in the Turkish banking industry using innovative products and processes made by web-based banking product channels used in Turkey with structural analysis. It was concluded that the number of products used in web banking services and consumers using these products is noticeably increasing in time. On the other hand, when compared to other world examples, using the Internet banking in Turkey has not reached the required level yet. Taking into account this fact and in order to spread eservices, it is more than important to take some precautions. Bridging the clash between the web infrastructure and the banking security industry, diversifying from banking products, strengthening the understanding the trend in using web banking will act to accelerate the development of web banking services more and more [8].

Another interesting approach is the approach of R. Jain who states that the "... policy makers in developing countries are increasingly focusing on national broadband plans (NBPs)". For example, politicians in India understand that broadband can accelerate the increasing contribution to those services and knowledge sectors of the economy of India, and also help to alleviate its poor delivery of physical services in such areas as health, education, banking, etc. This article documents the development in the Indian NBP. Based on previous studies, the main factors contributing to the success in the deployment and adoption of broadband were determined and estimation of the Indian NBP was performed [9].

Talking about the Internet banking and its introduction, a particular attention should be paid to banking risks. Such authors as Bruno E., Iacoviello G., Lazzini A., Tasca M. determine that the function related to the risk management in banks has considerably evolved lately: from an independent risk assessment for credit culture, which must entirely be taken into account. The term "risk" has gone beyond the frames of traditional measures such as credit, market and operational risks of corporate management, risks connected with fraud and reputation. Consumers benefit from new banking products based on the Internet platforms in terms of convenience and banking services with regard to cost reduction. However, the Internet itself is not a safe place and this problem with risks influences the entire banking industry from regulators and supervisors to financial institutions as such [10].

Banks begin to deliver quality online experience for customers and, as a result, the adoption of online banking continues to grow and is becoming an increasingly important competitive factor for banks in attracting and retaining their customers [11]. Online banking has changed its industry significantly in terms of channel usage, especially among young people [12]. The study on banks' strategic distribution channels confirms that "Bank customers are divided into the Internet banking segment and a branch banking segment and it is argued that the former is growing and the latter is declining" [14]. Similarly, the study conducted in China revealed that the barriers to online banking were mainly caused by risks, security and computer skills [15].

The conducted systemic analysis demonstrates the following: foreign experience related to the introduction of the 
Internet banking in the global community implies the integration and mobility for clients and alleviates banking operations. Undoubtedly, there is a need to take into account the potential and specific nature of every country in particular.

\subsection{Domestic approach to the study of the Internet banking: practical experience}

With regard to domestic development of the Internet banking, it arises from the system known as the "CustomerBank". The Russian Internet bank is traditionally considered alongside with the advent of the Internet banking system developed in Avtobank in 1998. This banking system was only available to particular individuals. One only needed a standard browser in order to get an access to one's account and be able to manage it. Identification information was stored on a special hardware device connected to a computer.

Nowadays, the customer does not need to install any special software. The client part of the system is implemented through a website or plug-in for a web browser, and authentication is two-factorial and includes a client entering the password and a one-time code received via SMS. Apart from that, most frequently the Internet banking systems are developed by third-party manufacturers.

The issues of efficiency and development of the Internet banking were highlighted in the Internet Banking Rank 2017, which is the sixth edition of the annual survey of online banking efficiency for individuals, carried out by the analytical agency Markswebb Rank \& Report. It includes the study of 36 systems of the Internet banking operating in Russia and an online survey of more than 3,000 Russian Internet users [16].

In the course of the study, the experts assessed Russian Internet banks in terms of their functionality and usability against more than 400 criteria. The bank that fully meets the needs of its users and has simple and convenient interface is the most effective, according to the study.

The study shows the following: as of 2017, the UralSib Bank, recently being one of the largest banks in the republic, takes the $7^{\text {th }}$ place in the ranking of Russian Internet banks for individuals, having progress by 6 positions at once. This fact indicates not only its very high level, but also the intention for improvement, including the field of RBS. The UralSib Bank actively develops electronic services and stimulates its customers to get remote services. It is mainly driven by an opportunity to offer its clients more attractive conditions for service through electronic channels. One can pay for services through RBS channels commission-free or with much lower commission than the bank's cash point offers. A client can open a deposit at a higher rate and make currency exchange transactions online at a more favorable rate. Such development tendency reduces the bank's expenses associated with the development of its branches and does not violate the interests of its clients [17].

The expediency of Internet banking for a particular category of customers is determined by the bank. Some banks provide remote access to legal entities only, while others - to individuals. Nevertheless, nowadays almost all successful banks actively provide all types of remote banking services including for various groups of users.

It was determined during the survey conducted by the information agency Banki.ru that at least one Internet bank is used by 35.3 million people, or $64.5 \%$ of all Russian Internet users. The number of Internet banking users in Russia has not changed for the current year: there is no longer an increase in the Internet banking audience that was observed several years ago [18].

Pensioners and people of pre-retirement age use the services of the Internet banking and mobile banking to the same extent as the younger generation.

This study indicates an interesting fact that the proportion of people at the age from 16 to 54 who regularly use mobile banking equals $63 \%$ while the percentage of the Internet banking users makes approximately $77 \%$. At the same time, among people at the age of 55 and above, 54\% use mobile bank, while the Internet banking has $77 \%$ of its users.

It is critical to point out the fact that the Internet banking is widely spread as a channel of banking services in settlements of different sizes. Among the citizens of the Russian Federation that live in cities with the population of less than 100 thousand and in the countryside there are approximately $58 \%$ of the Internet users that apply at least one Internet bank.

Due to such popularity of the Internet banking, the Central Bank tackles the security of this system for its users. Now the Internet banking will first be exposed to large-scale verification and then to total regulation by the Central Bank. The security check for all types of remote banking is supposed to be conducted in 2017. The security of the Internet banking will be tested in terms of protection from cyberthreats. Despite the fact that the Internet banking has been for a long time in Russia, it has never been controlled by the Central Bank. All commercial banks having the Internet banking provide the security of customer transactions via remote channels as they could or thought necessary [19].

Penetration of the Internet banking into the customer base varies dramatically from one bank to the other. The largest amount of the Internet banking users in relation to customers of all banks is represented by the Citibank and the Sberbank of Russia (65-66\%), whereas Rosselkhozbank, OTP Bank, AK BARS, Gazprombank and the Eastern Bank have the smallest amount (15-20\%).

Hence, the level of penetration of PBS in Bashkortostan with its relative overall number of adult users, having an access to the Internet, makes approximately 65\%. People with middle income from 20 to 50 thousand rubles per capita per month make the majority of the Internet banking users. People with a high level of income of over 50 thousand rubles per capita per month constitute only $19 \%$ of all Internet banking users. Users with a low level of income make nearly $43 \%$ or almost half of the audience [20].

As Figure 1 shows, the penetration of the Internet banking amongst its users is steadily increasing with the growth of 
personal income. However, people who earn more than 100 thousand rubles per capita per month are usually less likely to use the Internet banking.

\section{The proportion of users of Internet banks among Internet users with different levels of income per person in the family}

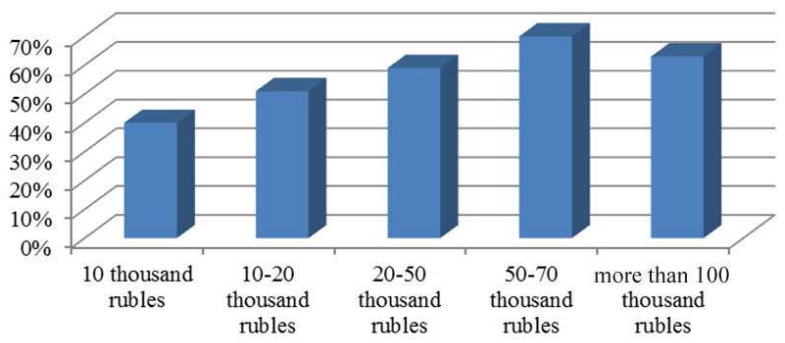

The proportion of users of Intemet banks among Internet users with different levels of income per person in the family

Fig.1. The proportion of users of the Internet banks among the Internet users with different levels of income per person in the family $*$

* Developed by the authors

There is a direct dependence between the experience of the Internet banking users and frequency of its use. Thus, it was defined that among people who have been applying the Internet banking for less than 1 year, only $22 \%$ visit the Internet bank more frequently than once a week. Moreover, the number of people with more than 3 years of experience exceeds $45 \%$. It can be stated that there is a considerable drop (from $20 \%$ to $7 \%$ ) in the number of customers that use the Internet bank once a month or even less.

Sberbank Online is considered the most popular and profitable Internet bank in Russia. It is used by approximately $81.8 \%$ of clients since this Internet bank has the biggest share of exclusive audience $-46 \%$ of people do not use other Internet banks at all. The most popular function is viewing account statements and transaction history. Three quarters of users make more than two transactions through the Internet bank per month. The vast majority of operations are accounted for by regular payments such as mobile communication, the Internet, transfers to accounts within the bank and payment of utilities.

The payment activity of users is also growing at a comparable pace; thus, the number of utility payers increases by $20 \%$ in the first 2 years of using the Internet banking. Besides, it is important to point out such operations as transfers to personal accounts within the bank.

\section{CONCLUSION}

Nevertheless, there are still restrictions and some drawbacks of such systems. Even interfaces of the best Russian Internet banks come up with some absurd solutions with regard to the end user, which is mainly imposed by various severe restrictions of software modules and platforms.

It is essential to present some statistical data in order to make the study verifiable. The paper presents economic benefits from multifactor authentication based on biometric USB-tokens. Initially, it is suggested to introduce such systems only for legal entities since they represent the target group when dealing with cyberattacks due to large sums of money available in accounts. The study of the market of biometric USB-tokens was carried out. According to its results, a solution of ISBC group - ESMART Token GOST was selected. This represents a cryptographic protection of information with hardware support of Russian cryptographic algorithms based on domestic MIK 51 chip manufactured by JSC NIIME and Mikron Plant.

The group of companies known as Mikron created the entire production chain from design to production of the ultimate product, which allows producing the whole range of high-tech products and solutions aimed at the mass market: RFID chips and tags, SIM cards, transit and bank cards with a chip, protected microchips for social cards and state identification documents. Mikron annually produces more than 400 million RFID tags, 50 million bank chips, 30 million bank cards, more than 5 million chips for the production of biometric passports and electronic documents. Mikron is also the largest Russian exporter of industrial microchips - more than 500 million microchips manufactured by Mikron are annually exported to Europe and South-East Asia for enterprises that produce various electronic equipment. The choice of tokens based on microelectronics produced by Mikron is justified by its ability to provide the necessary volume of production, without purchasing ready-made foreign solutions and technologies. Moreover, it eliminates the need to purchase an expensive license for their production and use, which is especially complicated under sanctions. This token exemplifies how biometrics allows effectively solving different tasks related to information security and protection. The advantages of such tokens include low cost, ability to be used as an electronic signature, and, in comparison with smart cards, there is no need for special readers, the cost of which is several times higher than the cost of USB-Tokens, with the same level of security provided. The secure controller, embedded in ESMART Token GOST, provides protection against attacks such as SPA, DPA, DFA. The intrusion sensors, light, impulse noise, voltage, temperature, as well as hardware integrity control sensors and erasability of EEPROM secure key information to protect against breaking the chip and unauthorized access. EEPROM is an electrically erasable reprogrammable permanent storage device and one of the types of nonvolatile memory.

Bashsomsnabbank accounts for $5 \%$ or from 500 million to 30 billion rubles. This indicator was calculated on the basis of data obtained from Marswebb lnternet Banking 2016 concerning the level of penetration of the Internet banking among legal entities and data of Bashkomsnabbank, which indicate approximately 5\% (formula 1) of legal entities.

$$
(75318 / 4.5 * 0.35) * 100=4.79
$$

where 75138 - number of clients (mln) - legal entities, using remote banking services of Bashkomsnabbank;

$4.5 \mathrm{mln}$ - number of registered legal entities in Russia; 
0.35 - level of penetration of the Internet banking amongst legal entities in Russia.

Based on the estimates of Group-IB and the Sberbank of Russia for 2015-2016, the legal entities in Russia suffered losses from cyberattacks making from 10 to 400 billion rubles, depending on evaluation as such. Proceeding from this assumption, one assumes that the distribution of cyberattacks in general will coincide with the number of users of the Internet banking and will make from 500 million to 20 billion rubles for Rosselkhozbank.

Table I. Intended economic effect from introducing USB-tokens ESMART Token GOST with biometrics

\begin{tabular}{|c|c|c|c|c|}
\hline \multirow{2}{*}{ Indicator } & \multirow{2}{*}{ Total } & \multicolumn{3}{|c|}{ Scope of introduction } \\
\cline { 3 - 5 } & & 2018 & 2019 & 2020 \\
\hline 1 & 2 & 3 & 4 & 5 \\
\hline $\begin{array}{c}\text { Number of } \\
\text { connected clients }\end{array}$ & 75,138 & & & \\
\hline $\begin{array}{c}\text { USB token } \\
\text { ESMART Token } \\
\text { GOST/USB, pcs. }\end{array}$ & 80,000 & 25,000 & 25,000 & 30,000 \\
\hline $\begin{array}{c}\text { Price per unit of } \\
\text { USB token } \\
\text { ESMART Token } \\
\text { GOST/USB, rubles }\end{array}$ & - & 1,486 & 1,545 & 1,607 \\
\hline $\begin{array}{c}\text { License value per } \\
\text { software unit (for 3 } \\
\text { years) }\end{array}$ & - & 1,634 & 1,699 & 1,767 \\
\hline $\begin{array}{c}\text { Expenses on } \\
\text { potential losses (7\%) }\end{array}$ & $1,822,371$ & $5,460,000$ & $5,677,770$ & $7,085,941$ \\
\hline $\begin{array}{c}\text { Total expenses, } \\
\text { rubles }\end{array}$ & $2,785,629$ & $8,346,000$ & $8,678,870$ & $108,313,669$ \\
\hline \multicolumn{1}{|c|}{} & & $*$ Developed by the author \\
\hline
\end{tabular}

The above calculations allow concluding that the share of costs related to the transition of legal entities to the system of multifactor authentication, including biometrics, makes from $55.7 \%$ to $1.4 \%$ of potential losses on 50 cyberttacks. Therefore, it seems advisable and reasonable to install this system.

In this regard, the development of RBS protection systems is aimed at the maximum possible cost and time associated with attacks. Such strategy excludes those people who cannot afford organizing and implementing attacks due to their poor financial potential. Maintaining the adequate level of information security requires a systematic approach and investments from a particular bank. Otherwise, a bank puts trustworthiness and loyalty of its customers at risk, since the latter ones perceive the Internet banking as a necessary tool of any bank they are dealing with.

At present, in terms of security of individuals, Bashsomsnabbank provides its customers with reliable security of remote banking operations, which is continuously ensured through leading domestic developments and innovations.

\section{References}

[1] R. Jayamaha, Global banking in transition opportunities and challenges, Association of Professional Bankers, pp. 1:27, 2002, 583 Luxmy Vivekanandan and Sanath Jayasena, Procedia - Social and Behavioral Sciences, 40, pp. $576-583,2016$.

[2] N. P. Mols, The Internet and the banks' strategic distribution channel decisions, International Journal of Bank Marketing, vol. 17, no.6, pp.295-300, 1999.

[3] R. Villavarajah, Changing face of banking moving towards branchless banking, Bankers Journal., vol. 26, no.2, pp. 7-10, 2008.

[4] Al Kharusi, MH. Al-Badi, AH. IT personnel perspective of the slow adoption of cloud computing in public sector: Case Study in Oman, 3rd international conference on big data and smart city (icbdsc), Muscat, OMAN, pp.179-186, 2016.

[5] G. Baptista, T. Oliveira. Understanding mobile banking: The unified theory of acceptance and use of technology combined with cultural moderators. Computers in human behavior, pp. 418-430, 2015.

[6] RR Deng, SAA Aziz, AHH Fadhillah, H Rosnan. Attitude formation towards internet banking of Islamic banks, Advanced science letters, pp. 2020-2023, 2016.

[7] L.Teran, C. Horst, BF. Valencia, P.Rodriguez, Public electronic payments. A case study of the electronic cash system in Ecuador. Third international conference on edemocracy \& egovernment (icedeg), Sangolqui, Ecuador, pp. 65-70, 2016.

[8] B. Sanli, B Hobikoglu, E. Development of the Internet banking as the Innovative distribution channel and Turkey example. World conference on technology, innovation and entrepreneurship, Istanbul, Turkey, pp.343-352, 2015.

[9] R.Jain, The Indian broadband plan: A review and implications for theory «Telecommunications policy», Indian Inst Management, IDEA Telecom Ctr Excellence, New Delhi, INDIA, pp. 278-290, 2014.

[10] The major risks in implementing new banking products, Euro and the European banking system: evolutions and challenges. International Conference on Euro and the European banking system - evolutions and challenges», ROMANIA, pp.328-333, 2015

[11] Keynote, Online banking critical to bank selection and brand perception, Keynote Systems Inc, 2008.

[12] R. Leichtfuss, D. Rhodes, C. Trascasa, S. Chai, M. Kumar, R. SchmidtRichte, Retail Banking: Facing the Future, The Boston Consulting Group, 2007.

[13] P. Kasturiratna, Internet Banking and E-Commerce, Association of Professional Bankers, pp. 58-63, 2005.

[14] N. P. Mols, The Internet and the banks' strategic distribution channel decisions, International Journal of Bank Marketing, vol. 17, no.6, pp.295-300, 1999.

[15] S. Laforet, and X. Li, Consumers' attitudes towards online and mobile banking in China, International Journal of Bank Marketing vol.23, no.5, pp. $362-380,2005$.

[16] GlobalCF0Study2010-2016, Network publication TheNewValuelntegrator, - Electronic text is given, 2017. Retrieved from http://www-935.ibm. com

[17] O. N. Dyakova, Remote banking services in the activities of banks, Izd. Mord. Un-ta them, no. 7, pp. 5, 2011.

[18] The study of the information agency Banki.ru, Retrieved from http://www.banki.ru/news/lenta/?id=9578909

[19] The survey of financial stability of the Central Bank 2016. Retrieved from http://www.cbr.ru/publ/?PrtId=stability

[20] Rating of the creditworthiness of Bashsnoshbank (PAO), FitchRatings. Inc., Russia, 2015. Retrieved from www.fitchratings.ru. 